\title{
The Role of Religious Fundamentalism in the Intersection of National and Religious Identities
}

\author{
Susilo Wibisono, Winnifred Louis, and Jolanda Jetten \\ School of Psychology, The University of Queensland, Brisbane, Queensland, Australia
}

\begin{abstract}
ndonesia has seen recent expansions of fundamentalist movements mobilising members in support a change to the current constitution. Against this background, two studies were conducted. In Study 1 , we explored the intersection of religious and national identity among Indonesian Muslims quantitatively, and in Study 2, we qualitatively examined religious and national identification among members of moderate and fundamentalist religious organisations. Specifically, Study $1(N=178)$ assessed whether the association of religious and national identity was moderated by religious fundamentalism. Results showed that strength of religious identification was positively associated with strength of national identification for both those high and low in fundamentalism. Using structured interviews and focus group discussions, Study $2(N=35)$ examined the way that self-alignment with religious and national groups develops among activists of religious movements in Indonesia. We found that while more fundamentalist activists attached greater importance to their religious identity than to any other identity (e.g., national and ethnic), more moderate activists represented their religious and national identities as more integrated and compatible. We conclude that for Indonesian Muslims higher in religious fundamentalism, religious and national identities appear to be less integrated and this is consequential for the way in which collective agendas are pursued.
\end{abstract}

Keywords: social identity, national identity, religious identity, fundamentalism, religiosity

Researchers often perceive fundamentalism as the driving force behind interreligious group conflict because it is argued to support authoritarian aggression (Altemeyer \& Hunsberger, 1992) or terrorist violence (Rogers et al., 2007). However, it is also clear that those who are driven by their fundamentalist identity to pursue particular group goals hold more identities than just their religious identity. We propose that how religious identity intersects with other identities - notably national identity — is important because it determines how that the religious identity takes shape and is defined. In particular, while both national identification and religious identification are associated with group loyalty (Druckman, 1994; Ysseldyk, Matheson, \& Anisman, 2010), the two identities can be perceived as more or less compatible, and this may be associated with religious-based collective action. We argue that it is important to examine the intersection of identities because, at times, the actions that emerge as a consequence of a particular form of intersectionality may be disruptive to the social fabric of nation states. For example, the demands by fundamentalist religious groups to legalise certain religious norms may be perceived as a demonstration of religious supremacy that can lead to disharmonious relationships among other religious groups (Kanas \& Martinovic, 2017) and ultimately damage national interests.

This is why we propose that it is important to gain a deeper understanding of the relationship of religious identity and national identity. Religious-based political action can not only exert a strong influence on societies (Kanas \& Martinovic, 2017; Verkuyten, Maliepaard, Martinovic, \& Khoudja, 2014), but it can affect group processes and identities at work in religious collective action (Ysseldyk et al., 2010). Such collective action may be represented in various forms, such as supporting religious-based political agendas (e.g., religious education in schools, legal ratification of religious-based rituals), lobbying for religious interests, or religious-based intergroup hostility (see Kanas \& Martinovic, 2017; Kanas, Scheepers, \& Sterkens, 2016).

In the present research, we explore the role of religious fundamentalism in the intersection of religious and national identity in Indonesia. In the second study, we

Address for correspondence: Susilo Wibisono, School of Psychology, University of Queensland, McElwain Building, Room 303, St Lucia QLD 4067, Australia.Email: s.wibisono@uq.net.au 
explore more specifically how active members of religious social movements in Indonesia understand the intersection of religious and national identity. We propose that this intersection determines the nature of activism on behalf of the group as well as the attributions that members make for events that are relevant to the religious group and nation. Before exploring these processes in greater detail, it is important to define key concepts.

\section{Definition of Key Concepts}

Despite the fact that there are a fair number of definitions of religious fundamentalism in different disciplines (Mavor, Louis, \& Laythe, 2011), many scholars have defined fundamentalism as a set of dogmatic beliefs or a literal adherence to a sacred text (Altemeyer \& Hunsberger, 1992; Liht, Conway, Savage, White, \& O'Neill, 2011; Williamson \& Ahmad, 2007). In this research, we will adopt a definition that is related to this generally accepted characterisation of the concept and define fundamentalism as 'the belief that there is one set of religious teachings that clearly contains the fundamental, basic, intrinsic, essential, inerrant truth about humanity and deity that must be followed, unchangeable and opposed by forces of evil' (Altemeyer \& Hunsberger, 1992, p. 118). This definition provides the basis of the Religious Fundamentalism Scale (RFS) employed in many studies (e.g., Asp, Ramchandran, \& Tranel, 2012; Beller \& Kroger, 2017; Blogowska \& Saroglou, 2011). In addition, Liht et al. (2011, p. 1) consider religious fundamentalism as a personal orientation that asserts a supra-human locus of authority, absolute truth and the appreciation of the sacred over the worldly experience. Considering the scriptural interpretation within religion, fundamentalism is described as a belief that a single text is absolutely authoritative and judged to be the final arbitrator of all other knowledge (Hood, Hill, \& Williamson, 2005, p. 3).

The other key concept in this research - national identity - is defined as one's sense of belonging to one state or nation (see Kanas \& Martinovic, 2017; Verkuyten et al., 2014; Verkuyten \& Yildiz, 2007). High national identification is associated with loyalty to the nation, and it is not surprising because such loyalty is expected by nations. Specifically, the modern nation state typically demands commitment to national interests and, at times, this may mean that the expression of particular identities other than the national identity (e.g., religious, ethnic, tribal, regional groups) may be curbed. In contrast, despite demanding loyalty, many contemporary nations honour that citizens may adopt multiple social identities in addition to the national identity (e.g., instead of feeling solely Indonesian, people may also consider themselves as Christians or Muslims). The latter intersection of identities appears to be promoted in Indonesia; Indonesia, which has a Muslim majority, does not formally legislate the Islamic social and legal order (Sharia) within its constitution, and respects its diverse citizenry.
Finally, we define religious identity as a sense of belonging to one religion (Kanas \& Martinovic, 2017), and those with a higher religious identity typically believe in a distinctive sacred worldview and an 'eternal' group affiliation (Ysseldyk et al., 2010). Many people associate themselves with their religious group, and for some this extends to seeing religious identity as more important than other identities. It is the relationship of religious and national identity that is the focus of the present article.

\section{The Relationship Between Religious and National Identities}

National identity can lead to a sense of citizenship with institutional commitments and increased participation in national development (Smith, 2001). In this sense, national identity can establish inclusiveness, as all members of a nation are considered ingroup members, irrespective of their various other identities (Meeus, Duriez, Vanbeselaere, \& Boen, 2010). However, perceived identity incompatibility between religious and national identities can lead to political action aimed at establishing religious-political governance, in order to seize power from more secular governments (e.g., as witnessed in the Iranian revolution, the Egyptian revolution, or the Hizbut Tahrir movement in Indonesia). Similarly, perceived incompatibility of national and religious identities may lead to state repression of religious congregations, schools, or doctrines, and even state violence against members of religious groups.

The perceived incompatibility of these identities can serve to drive people with dual identities to participate in political action that strongly supports the domination of one of these identities (Simon, Trotschel, \& Dahne, 2008). People whose religious identity trumps their national identity are more likely to perceive their religiosity as more central to their self-concept (Ysseldyk et al., 2010). The unique characteristics of religion (e.g., compelling emotional experience and moral authority that cannot be empirically disputed; Wellman \& Tokuno, 2004) may lead religious identity to be personally more significant than membership in other groups (Ysseldyk et al., 2010).

According to the ingroup projection model (Mummendey \& Wenzel, 1999), there should be a positive association between religious identity and national identity for members of a majority religion. This is because members of a majority religion (e.g., Indonesian Muslims) would be expected to project their religious identity onto the national identity, and to see these as mutually compatible and reinforcing, a pattern that often justifies calls for domination of the majority religion. For example, in Australia, where Christians are a majority, the Australian government may be called on to enact Christian values and beliefs (Cannold, 2011), and in Myanmar, a Buddhist majority has supported discrimination and even violence against Rohingyan Muslims, to maintain the status quo (Strathern, 2013).

However, we propose that the association between national and religious identities may differ for those who are 
more moderate versus those who are more fundamentalist in their beliefs. In the Indonesian context, it has been argued that a political discourse promoting mutual compatibility between national and religious identities is more strongly endorsed by Muslims who are more moderate in their religious beliefs (Khisbiyah, 2009; Takwin, Mudzakkir, Salim, Ahnaf, \& Hamdi, 2016). However, fundamentalist Muslims in Indonesia may highlight the obligation for Muslims to live under the rule of religious (Islamic) law and to be loyal to a world Muslim community. Thus, fundamentalist Indonesian Muslims may be more likely to believe that supporting nationalism deviates from Islamic norms and values. In light of this, one hypothesis is that religious identity and fundamentalist beliefs will interact to shape national identification. For higher fundamentalists, the positive association between religious and national identities may be weakened or even become negative.

We explore these processes in two studies. In Study 1, we quantitatively examine the role of measured religious fundamentalism on the link between religious and national identity in a community sample of general Indonesian Muslims. In Study 2, we qualitatively explore national and religious identification across four Islamic religious movements in Indonesia, two being more fundamentalist and two more moderate. Before introducing these studies in greater detail, we describe the specific historical context in Indonesia because this helps to develop a better understanding of the rationale for of our predictions.

\section{The Indonesian Context}

The Indonesian context provides a particularly interesting context for the study of the intersection of religious and national identities. Historically, the resistance to Dutch colonialism in the Netherlands-Indies, known today as Indonesia, was strongly influenced by religious motivations (Knaap, 2014). Following the 1998 political reform that abolished the dictatorship of the New Order government (1966-1998), the democratisation process in Indonesia has been significantly influenced by the rise of religious fundamentalism, associated with strong demands to change the national constitution to bring about an Islamic social order or Sharia (Takwin et al., 2016). Since 1998 there has been a growth of religious movements that strongly support constitutional change incorporating a new religious social order. For example, thousands of Muslims attended the Mujahidin congress in Yogyakarta in August 2000, demanding the implementation of Sharia in the constitution. One of the speakers emphasised that Muslims only have two choices: implementing Sharia in the country or dying as Mujahedeen (religious heroes in Islamic tradition; Takwin et al., 2016). This meeting spurred the growth of many new religious movements characterised as fundamentalist because of their aim of changing the national constitution to enforce Islamic laws (e.g., Khisbiyah, 2009; Ward, 2009).
Indonesia presently has a unique political system based on the Pancasila, a national philosophy that combines five underlying philosophies: belief in God, a just and civilised humanity, the unity of Indonesia, democracy led by the wisdom of deliberations among representatives, and social justice for the whole of the people of Indonesia (see Pohl, 2015). According to these principles, Indonesia is neither a secular state nor a theocracy. Most Indonesian Muslims believe that Indonesia is an Islamic state that already accommodates the core values of Islam through Pancasila (e.g., social justice, democracy, equity) rather than through formal Sharia rules (see Nakhleh, 2009; Pisani \& Buehler, 2017). Nevertheless, some Muslims perceive Indonesia to be a moderate secular state (Burhani, 2013), a stance that is unsatisfactory for religious fundamentalists who believe there is a religious obligation to establish an Islamic political system (Osman, 2010a, 2010b).

Consequently, fundamentalists perceive the current political system in Indonesia as a deep injustice toward Muslims, to the extent that the quasi-secular nation state is seen as an obstacle for Muslims to performing their religious obligation to be ruled by an Islamic political system (Muhtadi, 2009; Osman, 2010a). Consistent with this, Kanas and Martinovic (2017) found that religious identification was higher than national identification among both Muslims and Christians in Indonesia. This suggests that within the Indonesian context, religion provides a stronger basis for identification than nationality. However, a small positive association between national and religious identification was also found $(r=.15, p<.01$; Kanas \& Martinovic, 2017), highlighting the potential for religious and national identification to reinforce each other. Our research focuses on how religious fundamentalism affects the degree to which religious and national identities are seen as compatible. We approach this question through a mixed-method program of research with two studies.

\section{Study 1}

We explored the associations among religious identification, national identification, and religious fundamentalism quantitatively in an Indonesian Muslim community sample. In this study, we hypothesised that (1) there should be a positive significant association between religious identification and national identification, and (2) higher levels of religious fundamentalism weaken the strength of this association. More specifically, we predicted that more fundamentalist religious adherents should have a lower association between religious and national identification than more moderate religious adherents.

\section{Method}

\section{Participants}

One hundred and seventy-eight Indonesian Muslims $\left(38.2 \%\right.$ men, $\left.M_{\text {age }}=21.6, S D_{\text {age }}=6.5\right)$ were recruited. All participants were screened to ensure that they took at least 15 minutes to complete the survey (i.e., did not rush), 
while completing at least $90 \%$ of the survey. A large minority (39.7\%) were religious movement activists. According to the participants' ethnic group, $54.5 \%$ participants were Javanese, $10.1 \%$ were Sundanese and the rest came from the tribes in Sumatra, Borneo and Celebes Island. Although the effect size was unknown, based on previous research, we chose to collect a sample of greater than 150, which would deliver power of $>.90$ for an alpha of .05 and associations with small to moderate effect sizes $(f>$ .015).

\section{Procedure}

Participants were recruited via an online survey that was distributed through social media platforms. We recruited research assistants (RAs) from a regional Indonesian university in Yogyakarta to circulate the survey link within their student networks. They disseminated the link to their social media groups and friends (e.g., via Facebook, Instagram, WhatsApp), along with a brief introduction asking the participants to open, read and complete the questionnaires. Participants were compensated with entry in a lottery for a gift of internet quota of 100,000 rupiah. The spreadsheet with phone numbers required to contact winners was separated from the survey link ensuring that survey data were deidentified at all times.

\section{Measures}

As the original scales were in English, we developed the Indonesian version of the scales described below through back-translation processes. The first author, a native Indonesian speaker, translated the items into Indonesian (Bahasa). A native Indonesian with a doctoral degree in English literature then back-translated these items. After finishing this procedure, the second author who is a native English speaker compared the original items and the resulting back-translated items, and mismatches were reworded until the meaning was faithfully conveyed.

National identification. Items drawn from two scales were included. Specifically, three items were adapted from previous research in a similar Indonesian context (Kanas \& Martinovic, 2017): 'My most important characteristic comes from my nationality', 'I should respect my nation and its tradition', and 'Renewing national ideas is our national task', with a fourth item, 'I should always put national interest above ethno-religious group interest', which was omitted due to construct overlap with religious identity. Second, six additional items were included, adapted from the national identity scale of Ashforth and Mael (1989); for example, 'When someone criticises my country, it feels like a personal insult', and 'Successes of my country are my successes. ${ }^{1}$ Factor analysis with a single factor solution indicated that combining the nine items into one scale explained $39.5 \%$ of variance, with all nine items' factor loadings $>.480$. The combined scale also had a reliable alpha $(\alpha=.794)$.
Religious identification. We included items from two scales measuring religious identification, again combined with exploratory factor analysis. Specifically, three items were drawn from Verkuyten and Yildiz (2007), as adapted by Kanas and Martinovic (2017) in their study among Muslims and Christians in Indonesia: 'My most important characteristic comes from my religion', 'I should respect my religion and its tradition', and 'I should always put religious interest above ethnic and national interest'. In addition, six additional religious identification items were included from Ashforth and Mael (1989); for example, 'When someone criticises my religion, it feels like a personal insult' and 'When I talk about my religion, I usually say "we" rather than "they". Factor analysis with a single factor solution explained $50.1 \%$ of variance in the 10 items, with all factor loadings $>.38$ and a reliable alpha $(\alpha=.865)$.

Religious fundamentalism. Three scales were included and combined with exploratory factor analysis: the Religious Fundamentalism Scale (RFS; Altemeyer \& Hunsberger, 2004), Multi-Dimensional Fundamentalism Inventory (MDFI; Liht et al., 2011) and Intra-textual Fundamentalism Scale (IFS; Williamson \& Ahmad, 2007). The RFS provided 12 items, with six positively worded - for example, 'God has given humanity a complete, unfailing guide to happiness and salvation, which must be totally followed'; and six reverse-scored items - for example, 'No single book of religious teachings contains all the intrinsic, fundamental truths about life (recoded)'. The MDFI generated an additional 15 items - for example, 'Obeying God is the most important ingredient in order to grow as a person', 'True religion never changes', and 'Most people would come to accept my religion if they would not be blinded with strange ideas'. Finally, the IFS provided five items about beliefs regarding sacred scriptures - for example; 'Everything in the sacred writing is absolutely true without question'. A factor analysis of the items together with a single factor solution explained $34.8 \%$ of variance, with factor loadings $>.362$ generating a single reliable scale, $\alpha=.922$, after removing four items due to factor loadings $<.3$. The four under-performing items were 'The basic cause of evil in this world is Satan, who is still constantly and ferociously fighting against God', 'There is a particular set of religious teachings in this world that are so true, you can't go any 'deeper' because they are the basic, bedrock message that God has given humanity', 'People of religions other than mine are missing in regards to their potential to grow', and 'It is important to distance oneself from movies, radio and TV'.

\section{Results}

\section{Descriptive Findings and Correlational Analysis}

Table 1 shows the means and standard deviations for the main variables. Religious identification and national identification were positively associated $(r=.440, p<.001)$. However, religious fundamentalism was only significantly 
Table 1

Descriptive statistics and correlational analysis of variables used

\begin{tabular}{lllllll}
\hline & & \multicolumn{5}{c}{ Correlation } \\
\cline { 3 - 6 } Variables & $\begin{array}{l}\text { Descriptive } \\
\text { statistics Range }\end{array}$ & Mean & $S D$ & 1 & 2 \\
\hline National identification & $1-6$ & 4.715 & 0.62 & & \\
Religious identification & $1-6$ & 4.809 & 0.72 & $.440^{* * * *}$ & \\
Religious fundamentalism & $1-6$ & 4.605 & 0.73 & .108 & $.668^{* * *}$ \\
\hline
\end{tabular}

Note: ${ }^{*} p<.05, * * p<.01,{ }^{* * *} p<.001$.

positively correlated with religious identification $(r=.668$, $p<.001)$, and not with national identification $(r=.108$, $p=.151)$.

\section{Regression Analysis}

Moderated multiple regression analysis was used to analyse the interaction of religious identification and fundamentalism in predicting national identity. The interaction variable was created by multiplying the mean centred score of both predictors to minimise multicollinearity between predictors. Religious identification and fundamentalism were entered at Block 1 of the regression and the interaction was entered at Block 2 to determine whether it explained additional variance over and above that of the direct effect of the two predictors. In Block 1, when the direct effects were considered, the model accounted for significant variance, $R^{2}$ ch. $=.256, F(2,175)=30.15, p<$ .001 . Inspection of the coefficients revealed that religious identification was positively related to national identification, $\beta=.67, \mathrm{~b}=.548, S E=.075, p<.001, s r^{2}=24.5 \%$. On the other hand, controlling for religious identification, religious fundamentalism was negatively related to national identification, $\beta=-.34, \mathrm{~b}=-.283, S E=.074, p<$ $.001, s r^{2}=6.3 \%$. In Block 2, the interaction between religious identification and fundamentalism was not significant, $R^{2}$ ch. $=.011, F(1,174)=2.67, \mathrm{~b}=-.094, S E=$ $.057, p=.104, s r^{2}=1.1 \%$. The trend was for the association between religious identity and national identity to be stronger for those lower in fundamentalism $(\beta=$ $.72, \mathrm{~b}=.616, S E=.080, p<.001)$ than for those with higher levels of fundamentalism $(\beta=.56, \mathrm{~b}=.479, S E=$ $.092, p<.001)$, but the difference was not reliable. Post hoc power analysis indicates that the power to detect an obtained effect at the .001 level was .96 for the overall regression in predicting national identification, and power to detect the focal interaction, with an alpha of .05 for the observed effect size for the interaction coefficient (i.e., $\left.f^{2}=0.15\right)$ of .99 . It therefore appears that the moderation trend should not be interpreted as reliable.

\section{Discussion}

Study 1 demonstrated the positive association of religious identification with national identification (Hypothesis 1). However, the interaction between religious identity and religious fundamentalism in predicting national identity (Hypothesis 2) did not reach conventional levels of sig- nificance. In other words, even though the trend was in the predicted direction, the result indicated that the association of strength of religious and national identification was not significantly different between participants with low and high fundamentalism.

Even though Study 1 shows that more fundamentalist and more moderate Muslims did not differ significantly in how they perceived the relationship between national and religious identification, we considered exploring support for our hypotheses in another way, and we turned our attention to a closer consideration of the content of religious and national identities in a second study. The content of identities may be particularly important when considering recent developments in Indonesia that may have affected how fundamentalists construe the content of national and religious identification. Specifically, as a movement, religious fundamentalism in Indonesia aims to reform society by radically changing laws, morality, social norms, and political configurations to align with religious tenets to create a more traditional society (Haynes, 1995). This aim contradicts with the spirit of nation to be politically self-determining (Rieffer, 2003).

In sum then, in Study 1, the overall positive association between religious and national identification highlights the mutual reinforcement that each provides for Muslims in our sample. Yet, the question remains to what extent the content of the identities differs between moderates and fundamentalists. We turned to this question in Study 2.

\section{Study 2}

The purpose of Study 2 was twofold. First, we aimed to examine the role of religious fundamentalism in the intersection of national and religious identification among two different patterns of religious movements in Indonesia: moderate and fundamentalist movements. Specifically, how do activists describe the content and relationship between their national and religious identity?

Second, we explored the consequences of a particular relationship between national and religious identification and focused on the consequences for participants' willingness to engage in collective action. Specifically, do participants of moderate and fundamentalist movements perceive that their religious and national identities are integrated or conflicting and what are the consequences of this for collective activism?

To examine this, we conducted a qualitative study with the leaders and activists of moderate Islamic movements (i.e., movements that do not support the legalisation of Sharia for the sake of unity), as well as leaders and activists of fundamentalist Islamic movements who do support the legalisation of Sharia in Indonesia. We conducted structured interviews with the leaders and focus group discussions with the activists. We decided to address these research questions using a qualitative approach that enables us to draw on activists' experience of involvement in religious organisations. In addition, a thematic analysis 
Table 2

Participants involved in Study 2

\begin{tabular}{ll}
\hline Organisation & Interviewee(s) \\
\hline Moderate 1 & $\begin{array}{l}1 \text { leader and } 8 \text { activists (100\% male, } M_{\text {age }}=34.5 \text {, } \\
S D=7.8)\end{array}$ \\
Moderate 2 & $\begin{array}{l}1 \text { leader and } 9 \text { activists (100\% male, } M_{\text {age }}=28.7 \text {, } \\
S D=4.2)\end{array}$ \\
Fundamentalist 1 & $\begin{array}{c}1 \text { leader and } 6 \text { activists (100\% male, } M_{\text {age }}=37.2 \text {, } \\
S D=9.3)\end{array}$ \\
Fundamentalist 2 & $\begin{array}{l}1 \text { leader and } 8 \text { activists (100\% male, } M_{\text {age }}=31.7 \text {, } \\
S D=9.8)\end{array}$
\end{tabular}

(Clarke \& Braun, 2017) allowed us to analyse the psychological dynamics related to the intersections of different social identities.

When studying the content of identities, it should be noted that there are different categories of fundamentalists, with a range of political orientations (e.g., some are conservative, such as U.S. Protestant evangelical Christians; some are revolutionary such as some Islamist groups in Indonesia; and some are racist such as the KKK in the United States), including some nationalist-oriented derivatives of Hinduism and Buddhism (Haynes, 1995). In the context of Indonesian Muslims, some religious fundamentalist groups feature a desire to unite the world under the domination of Islam (see Muhtadi, 2009; Osman, 2010a). Such elements conflict with national norms emphasising a specific, bounded territory (Rieffer, 2003).

\section{Method}

\section{Participants}

Data were gathered through interviews and focus group discussions. We interviewed the leaders of religious organisations, while activists participated in facilitated group discussions. We approached two organisations that were identified according to the criteria described above as more fundamentalist and two that were more moderate. Four leaders and 31 activists of religious organisations were recruited, with interviews conducted in their respective offices (see Table 2). Leaders were not present during the activists' discussion groups, as these were held at different times. The samples of activists were recruited by organisations. All of the interviewees were men, a point that we return to in the discussion.

\section{Interview}

In this data collection, the interviewer and interviewees covered a range of topics based on a set of semistructured interview questions (listed in the Appendix). The organisations' leaders were asked about (a) the organisational aims and missions, (b) the organisational vision regarding the intersection of religion and nation, (c) the organisational strategy to strengthen the members' identification, and (d) the perceived obstacles in strengthening members' identity. Furthermore, activists were asked about (a) the background of their activism in the organisation, and (b) the process of maintaining religious and national identification as an activist.

\section{Coding and Analysis}

The data from the interviews and focus groups were transcribed and analysed using thematic analysis (Clarke \& Braun, 2017). Thematic analysis is a foundational method for qualitative analysis (Braun, Clarke, \& Weate, 2016), in which we identify, analyse and report the patterns (themes) within the data. In this way, we acknowledge how individuals make meaning of their experiences, and how the broader social context impinges on those meanings. In Study 2, we adopted the six steps of thematic analysis (Clarke \& Braun, 2017), which include: familiarisation with the data by transcribing the recorded data; generating initial codes to find interesting features; searching for themes through collating codes into potential themes; reviewing themes by checking whether the themes work in relation to the coded extracts and the entire data set; defining and naming the themes to refine the specific of each theme; and producing a report to answer the research questions.

A codebook was created prior to starting the data analysis. The codes were created based on the interview and focus group discussion throughout the process of data collection. This codebook was edited, updated, changed, and reorganised as the analysis proceeded. The first round of analysis focused on the statements where participants answered interview questions. This dataset was then coded, elaborating the two core questions in this research relating to: (1) whether the relationship between religious and national identification was construed as conflicted or compatible, and (2) the consequences of compatible or conflicted representations of religious and national identification.

\section{Results}

The recorded interview data from four leaders of the religious organisations and 31 activists representing each organisation were transcribed and categorised into two different themes based on the research questions. Within each section, we compare fundamentalist and moderate organisations for similarities and differences. Below, we elaborate the themes with specific citations, and each citation within this result is completed with the code that refers to the classification of the organisation (e.g., F-1 = fundamentalist $1, \mathrm{M}-2=$ Moderate 2 ), the position of the interviewee (e.g., $\mathrm{L}=$ leader, $\mathrm{A}=$ activist), and the line (e.g., $567=$ the statement taken from line 567).

\section{The Intersection of Religious and National Identification}

Our study focuses on three different social identities within the members of the sampled organisations: as Muslim, Indonesian, and as an organisational activist. We analysed the participants' narratives for any statement relevant 
to the intersection between their religious and national identification.

Our analysis revealed that the theme of congruent versus incongruent understandings of religious and national identification were prominent in the narratives of moderate and fundamentalist activists. In line with the findings of Study 1, fundamentalist activists were more likely than moderate activists to perceive that their Muslim identity cannot be compared with other social identities such as nationality, and that the Muslim identity predominates over other identities. This is evident from the following quote by one of the fundamentalist participants.

Certainly, Islam is the eternal identity from living in the world to living [in the] afterlife. We will be gathered in afterlife not based on nationality, we will not be gathered as Indonesian. No ... We will be gathered based whether we have faith or not. The people with faith will be classified again based on their obedience to God. (F-1-L-281)

For members of the moderate groups, in contrast, national and religious identities were more integrated, and participants expressed the belief that national identity is a consequence of Islamic faith. Among moderate Muslims who see themselves as prototypical of Indonesian Muslims, religious identification appeared to be more positively associated with national identification.

Religion and nationalism are like two poles that can't be separated from each other. Because defending the nation is part of the faith. (M-1-L-60)

... we also campaign that the unitary state of Indonesian republic [NKRI] is fixed [i.e., countering the campaign to formalise Sharia or even to establish an Islamic state]. And we make it as our slogan. These two sides, religiosity and nationalism, are our identity. And, we believe that [the Republic of Indonesia] is the unchangeable form that cannot be bargained away. It means we have to guard the nation. We guard two things: our religion and our nation. (M-1-L-309)

\section{The Relation Between Religious and National Identity and Its Consequences}

Further exploring the narratives that described participants' experiences as a religious activist, we identified three themes that related to consequences of the interplay between religious and national identifications.

\section{Radical change is needed to save the nation versus the un-} changeable form of the contemporary Indonesian state. A first theme related to the extent to which the participants pursue a systemic change within the nation versus defending the perceived unchangeable form of the current state. Fundamentalist activists perceived that there had been a failure of the state to facilitate the Muslim religious obligation to live under a religious social order and to become the perfect ( $k a f f a h)$ Muslim. In addition, they believed that becoming a perfect Muslim means living under the rule of Islam as whole. Hence, the fundamentalist activists believed that by working to create a religious social order throughout the nation, they would have an opportunity to save the nation.
We perceived it [Indonesia] as a country that hasn't applied God's law. It maybe even has disobeyed it. On the other hand, as a Muslim, we are ordered to implement what we believe in. Islam told us to become a perfect [kaffah] Muslim, or Muslim as a whole. What does 'a whole' mean? It means in every aspect of our lives, it has to be filled with Islam. Therefore, as Muslim, because we love our country, this country, we strive to make Islam the one and only law that applies in our society. (F-1-A-159)

Priority is my identity as Muslim. It's part of our contribution to religion. So, it is not just about praying five times a day, but we have to apply and call others (dakwah) in our nation life to build the country. (F-2-A-43)

On the other hand, moderate activists declared their commitment to the integrity of the nation under the current form of the unitary state. The moderate activists believed that loving the nation is a focal indicator of their religious faith. This is evident from the following extracts by moderate activists.

When we claim to be a member of [the organisation], of course we will take care and maintain the integrity of [the Republic] because [the organisation] is one of the organisations that has contributed to the independence of this republic. Therefore, it is necessary for each [the organisation's] members to preserve the unity of Indonesia. (M-2-A-127)

It is clear that [the organisation] always puts forward principles from Islam as part of faith relating to mercy of the universe, high tolerance, and love of nation. (M-1-A-8)

Furthermore, one activist from the moderate organisation (Moderate 1) indicated that it not only integrates religious and national identity, but also protects local traditions or cultural diversity within the nation:

In addition, [the mission of the organisation] also relates to the ethnicity, especially the Java ethnic group. [The organisation] declares itself to be the protector of tradition and it motivates me to join because I think that this country should be balanced, so we love our country and we also protect the local traditions. (M-1-A-53)

Supporting versus rejecting the legalisation of Sharia within the national constitution. Although much debated, the inclusion of Islam as part of a political order is a mainstream norm among Muslims. Religious identification appeared to dominate over national identification, and this speaks to the strong demand to legalise Islamic social order in the constitution, and for some, includes establishing an Islamic state. It is supported by the collective thinking among fundamentalist activists who strongly supported the legalisation of Sharia within the constitution. They also expected the current constitution to change, whereby the national philosophy (which was seen as unworkable) would move towards a more theocratic religious rule. For example, fundamentalist participants stated:

Indeed, [the organisation] calls the country leaders to implement Islam in all aspects of life. (F-1-L-569)

The way I see it, 'Pancasila' (the national foundational philosophy) is merely a philosophy that doesn't create a system. We can't find anywhere in Pancasila a guide telling us how to organise our 
educational system, social system, or political system. So when it doesn't create a system, it won't work. (F-1-A-81)

The expectations are ... that who gets the benefit is the Islamic ummah (worldwide Muslims) because we are an Islamic organisation that fights for Islam and its benefits must be for Muslims. $(F-2-L-3)$

'What is Sharia?' It starts from that Sharia tells us to cut thieves' hand, Sharia is a bank, Sharia is polygamy, for instance. Well, then Sharia is the implementation of Islam as a whole in all parts of life. (F-1-L-174)

On the other hand, moderate activists were more likely to express the belief that the current form of the state is unchangeable:

The unitary nation of Indonesian republic (NKRI) is an absolute. That is our primary struggle. $(M-1-A-265)$

If there are groups threatening the sovereignty of the current form of Indonesia (NKRI), we will release the highest level of mobilisation, which involves weapons. (M-1-A-304)

Moderate activists were more likely than fundamentalists to believe that the role of Islam in social and political life does not entail the formation of an Islamic social order but rather taking core Islamic values and integrating them into the existing democratic political system. For example, a moderate participant stated:

So our commitment is that Indonesia is not a formal Islamic state but a substantive Islamic state. Within this state, secular values must be replaced with Islamic values. So, the composition remains the same. Muslims want this current form of the state, although (it is) not formally an Islamic state, but there are more and more Islamic values adopted within it. (M-2-L-136)

External versus internal attribution of disadvantages. As a consequence of the difference in the extent to which religious and national identities have been integrated, different attribution styles emerged when discussing current issues within Muslim societies. Individuals whose religious identification appeared to dominate other identities tended to protect their religious collective identity by making an external attribution for disadvantages within Muslim societies. In particular, fundamentalist activists tended to attribute the roots of many social problems externally; for example, to a Western conspiracy that aims to prevent the progress of Muslims. Such external attributions are likely to reinforce the superiority of religious identification over national identification. These participants were more likely to see the adoption of Western systems by Muslims as the cause of their chronic problems.

So, this world, with the current monetary system, wealth is not distributed to Muslims, but non-Muslims. Also, Muslims don't have any instruments to control their properties, but they (nonMuslims) have! They have The Fed, they have IMF, World Bank and they can actively 'play' with those. And Muslims around the world, they have nothing, they just suffer. (F-1-L-508)

Because the system used by Muslims is a Western system. As a simple instance, in Islam, the monetary rule should base on gold and silver. But, with the current system, with paper money, although we have similar papers as used in printing American dollar, we cannot produce our money. (F-1-L-517)

A war between Muslims and non-Muslims keeps running and Allah has told us (through the Quran). It was a repeated history since the era of Adam. In our term, it is a battle between good and evil. So, Muslims should aware of that. (F-2-L-775)

On the other hand, moderate activists, who were more likely to integrate religious and national identification, also gave external attributions for some social problems, but they were also more likely to attribute the causes of disadvantage among Muslims to Muslims themselves. For instance, moderate activists did not seem to feel threatened by criticism toward Muslims as a group.

(Q: What should be done by Muslims to solve the problems?) A: A lot of us [Muslims] don't want to understand that learning is a process. We want to take success instantly. Well, if it is applied in worship field or searching for the understanding in Islam, we can't just skip to the end. The education in Islam should be based on the process, [we] can't run it instantly. (M-1-L-380)

Muslims are the majority [in Indonesia], but related to the economy, we lose against Chinese $e^{2}$ in Indonesia. We cannot blame them, but blame ourselves [Muslims]. Why is our economy not advanced? (M-2-L-288).

\section{Discussion}

Building on Study 1 findings, we found in our second study that there are differences in the way that fundamentalist and moderate activist construe the relationship between their national and religious identification and the content of each identity. We found that religious identification (being a Muslim) was the dominant identity among activists of fundamentalist organisations, and national identity was construed as incompatible with 'true' Islam. In contrast, activists from moderate organisations were more likely to construe the religious identity (being a Muslim) and national identity (being an Indonesian) as compatible. They were more likely than fundamentalist activists to balance the two identities, and they emphasised that the current form of Indonesia adapts to and expresses the core values of Islam.

This difference in perceived compatibility appears to be related to the different norms to support or oppose the legislation of religious social order in the national constitution and to attribute the disadvantages within Muslim societies externally or internally. In particular, moderate Muslims who integrated their national and religious identity were more likely to reject the legislation of Sharia. They believed that the manifestation of Islam in political life should be focused on the representation of Islamic values rather than on the formalisation of Islamic laws in the constitution. Among the fundamentalist activists, the dominance of religious identification over national identification seemed to co-occur with a greater intention to support radical change by changing the constitution by including Sharia law. They proposed that becoming a perfect (kaffah) Muslim means to realise and adopt Islam in every 
aspect of life (e.g., amputation of the hand for thieves, financial management referring to Sharia rules). Also, for some, the superiority of religious identification over national identification implies the need to protect religious identification. This protection leads to a tendency to attribute the root causes for global Muslim disadvantages to external causes. For instance, the low level of welfare in Muslim majority countries was attributed to the global conspiracy led by Western governments.

It should be noted that the fact that participating activists were recruited by leaders, and that participants were a convenience sample drawn from regional activists is a clear limitation of the study. As a result of this form of recruitment, participants were not representative of the broader fundamentalist and moderate Muslim communities; for example, all leaders were men, and all activists selected by leaders for interviews were men. Future research should focus on exploring the relationship between national and religious identification among more diverse samples in terms of region and gender (Duriesmith, 2018).

\section{General Discussion}

Historically in Indonesia, religious values are linked to the prolonged struggle against colonialism for independence. Not surprisingly, this led to the development of cultural norms for Muslims to be proud of their nation (Burhani, 2013). This is also evident from a popular saying that 'loving the nation is part of the faith' (Arabic: hubbul wathan minal Iman).

In Study 1, national identification was significantly correlated with religious identification, but religious fundamentalism did not significantly moderate the association. In Study 2, the picture was more complex, in that many fundamentalists appeared to spurn nationalism as they emphasised the role of religion, as revealed by God, to lift up all peoples of the world through the implementation of a transnational religious social order across national borders. These fundamentalist activists perceived their religious identity as dominant, and to some extent incompatible with nationalist views. In contrast, Muslims who are members of moderate organisations were more likely to integrate their religious and national identities.

This difference in identification between fundamentalist and moderate activists may have consequences for the way in which collective agendas are pursued. Fundamentalist activists have a strong intention to demand radical changes to the nation, while moderates tend to defend the current political system. Social identification has a strong power to motivate adherence to group norms and rules governing social behaviours (Bradford, Hohl, Jackson, \& McQueen, 2015). Therefore, people who give precedence to their religious identity over their national identity may adhere to the salient religious (Islamic) norms of implementing Islamic laws in the political system. In the Indonesian context, this relates to the demands for the legalisation of Sharia within the national constitution. Fundamental- ist activists whose main social identity is one of religious identification perceive this norm (i.e., implementation of Islam in political rules and legalisation of Sharia) as their collective agenda. In addition, the tendency of externally attributing blame in explaining the root causes of ingroup (Muslim) disadvantages is also noted as a strategy that reinforces their religious identification.

It must be acknowledged that our data do not speak to causal relationships among the variables. The theoretical model tested in Study 1 puts religious identity and fundamentalism as antecedents of national identity, but it seems likely that the influence is bidirectional. The acceptance or rejection of religious norms toward nationalism both produces and is produced by different patterns of religious orientation: moderate and fundamentalist. In the longer term, whenever national identity seems to be in conflict with valued religious identities, fundamentalism may flower. In addition, when fundamentalism grows, social conflict with inclusive or tolerant nation-states will be promoted. What these data highlight is that it is the content of the respective identities (and their representation as mutually supporting versus conflicting) that varies across fundamentalists and moderates, more than the strength of the associations per se.

The association between group identification and willingness to engage in collective action is established in previous research (Kanas \& Martinovic, 2017). In the more specific context of dual identification (i.e., religious and national identification), Kanas and Martinovic (2017) found that religious identification was related to lower engagement on collective action when national identification is high. What the present data highlight is that actors with high or low levels of religious and national group identification may be engaging in collective action for quite different political purposes. As shown in Study 2 , fundamentalist activists were more willing to engage in collective action that demands the mainstreaming of religious norms in national life, while moderate activists were resolute to defend the pluralistic status quo.

\section{Strengths, Limitations and Future Directions}

It should be noted that our analysis does not expect the same association between religious and national identities to hold across all contexts. Historically, various national movements have had a religious element, which may either be strongly connected (e.g., national movements in Ireland and India in the 20th century), or separated (e.g., the nationalist movement in Turkey led by Mustafa Kemal, which endorsed secular rather than religious political governance). More broadly, a positive association between religious and national identities should (according to the ingroup projection model; Mummendey \& Wenzel, 1999) appear more frequently for members of a majority religion than for religious minorities.

In examining religious and national identities, the present research benefits from a mixed-method approach 
that considered a theoretically and socially important research question using samples of religious activists as well as students. While a great deal of research has considered the impact of Muslim fundamentalism in recent years, the voices of moderate and fundamentalist religious actors are too rarely heard in this debate.

Yet the present research also has a number of limitations. Measurement within the quantitative study used primarily European or North American scales developed in Christian contexts, and future research should explore multidimensional or nuanced aspects of Islamic fundamentalism and its political correlates (e.g., Doosje et al., 2016; Stankov, Saucier, \& Knezevic, 2010; Webber et al., 2017). In addition, longitudinal or experimental work could be conducted to begin to test the bidirectional association that we propose between growing fundamentalism and lower perceived compatibility of national and religious identities.

\section{Conclusion}

In this study, we questioned how the experience of moderate and fundamentalist religious activists in Indonesia related to their religious and national identification. We also explored the implications of seeing conflict between these two focal social identities. We found that strength of religious identification was associated with strength of national identification, but that the content of the identities was quite different for more fundamentalist and moderate respondents. Moderate activists perceive their national identification as congruent with their religious identification, and believe that national commitment is a consequence of their religious faith. Moderate activists tended to perceive that the nation-state should be supported in its current form. In contrast, fundamentalist activists emphasised that their religious identity is an identity dominating other social identities. These activists sought to create a radical change by legislating religious social order (Sharia) within the national constitution.

Across the two studies, the present research contributes to knowledge by highlighting the importance of religion to nationalism in Indonesia, and by specifically highlighting how the nature of the relationship changes among more moderate versus more fundamentalist Muslim activists and community members.

\section{Acknowledgments}

We would like to acknowledge the Indonesian Endowment for Educational Fund (LPDP) of the Indonesian Republic who supported the first author for doctoral research at the University of Queensland (Australia).

\section{Appendix}

List of questions for guidance of the interview process with the leaders and facilitated group discussion with the activists

\begin{tabular}{l}
\hline Interviewee $\quad$ Basic questions \\
\hline Leader \\
mission? \\
Does the organisation strengthen the commitment of \\
members to the nation, to the religion, or both? When \\
is one type of identity more important? \\
How does the the organisation develop feelings of pride \\
and commitment in members of the organisation? \\
What are the obstacles perceived by the organisation? \\
Do the members feel that they have similar values and \\
aims as other members? How do you evaluate their \\
identities? \\
How does the organisation strengthen the positive \\
attachment among members? \\
Could you please tell me about the background of your \\
activism in this organisation? \\
How do you describe yourself as Muslim and as \\
Indonesian? Does your activism in organisation \\
influences how you define yourself? \\
To support this organisation, how important is the \\
commitment of members to the nation, to the religion, \\
or both? \\
When is one type of identity more important?
\end{tabular}

\section{Endnotes}

1 Comparatively little quantitative work has been conducted in the Indonesian context, and therefore we chose to test the extent to which multiple scales for national identification, each with slightly different operationalisations, cohered to create an inclusive scale. A similar approach was taken with religious identity and religious fundamentalism.

2 Chinese Indonesians are a minority group who are seen to be non-Muslim, wealthy and economically dominant, and who have attracted prejudice on those grounds (e.g., Setijadi, 2017).

\section{Author Contributions}

SW and WL conceived the studies and were responsible for overall planning and direction. JJ contributed to the design of the study. SW carried out the interviews, online surveys, data management and analysis. WL and JJ contributed to the analysis process both with regard to the qualitative and quantitative data. SW took the lead in writing the manuscript, with revisions based on feedback from WL and JJ.

\section{References}

Altemeyer, B., \& Hunsberger, B. (1992). Authoritarianism, religious fundamentalism, quest, and prejudice. The International Journal for the Psychology of Religion, 2, 113-133.

Altemeyer, B., \& Hunsberger, B. (2004). A revised religious fundamentalism scale: The short and sweet of it. The International Journal for the Psychology of Religion, 14, 47-54.

Ashforth, B.E., \& Mael, F. (1989). Social identity theory and the organization. Academy of Management Review, 14, 20-39. doi: $10.2307 / 258189$

Asp, E., Ramchandran, K., \& Tranel, D. (2012). Authoritarianism, religious fundamentalism, and the human prefrontal cortex. Neuropsychology, 26, 414-421. doi:10.1037/a0028526 
Beller, J., \& Kroger, C. (2017). Is religious fundamentalism a dimensional or a categorical phenomenon? A taxometric analysis in two samples of youth from Egypt and Saudi Arabia. Psychology of Religion and Spirituality, 9, 158-164. doi:10.1037/rel0000085

Blogowska, J., \& Saroglou, V. (2011). Religious fundamentalism and limited prosociality as a function of the target. Journal for the Scientific Study of Religion, 50, 44-60. doi:10.1111/j.1468-5906.2010.01551.x

Bradford, B., Hohl, K., Jackson, J., \& MacQueen, S. (2015). Obeying the rules of the road: Procedural justice, social identity and normative compliance. Journal of Contemporary Criminal Justice, 31, 171-191.

Braun, V., Clarke, V., \& Weate, P. (2016). Using thematic analysis in sport and exercise research. In B. Smith \& A.C. Sparkes (Eds.), Routledge handbook of qualitative research in sport and exercise (pp. 191-205). London, UK: Routledge.

Burhani, A.N. (2013). Defining Indonesian Islam: An examination of the construction of the national Islamic identity of traditionalist and modernist Muslims. Islam in Indonesia: Contrasting Images and Interpretations, 16, 2547.

Cannold, L. (2011). Australia's fading separation between church and state. $A B C N e w s$. Retrieved from http://www.abc. net.au/religion/articles/2011/05/13/3216153.htm

Clarke, V., \& Braun, V. (2017). Thematic analysis. Journal of Positive Psychology, 12, 297-298. doi:10.1080/ 17439760.2016.1262613

Doosje, B., Moghaddam, F.M., Kruglanski, A.W., de Wolf, A., Mann, L., \& Feddes, A.R. (2016). Terrorism, radicalization and de-radicalization. Current Opinion in Psychology, 11, 7984. doi:10.1016/j.copsyc.2016.06.008

Druckman, D. (1994). Nationalism, patriotism, and group loyalty: A social psychological perspective. Mershon International Studies Review, 38, 43-68.

Duriesmith, D. (2018). Hybrid warriors and the formation of new war masculinities: A case study of Indonesian foreign fighters. Stability: International Journal of Security and Development, 7, 1-16.

Haynes, J. (1995). Religion, fundamentalism and ethnicity: A global perspective (UNRISD Discussion Paper 65). Geneva, Switzerland: United Nations Research Institute for Social Development (UNRISD).

Hood, R.W., Hill, P.C., \& Williamson, W.P. (2005). The psychology of religious fundamentalism. New York, NY: The Guilford Press.

Kanas, A., \& Martinovic, B. (2017). Political action in conflict and nonconflict regions in Indonesia: The role of religious and national identifications. Political Psychology, 38, 209225. doi:10.1111/pops. 12345

Kanas, A., Scheepers, P., \& Sterkens, C. (2016). Religious identification and interreligious contact in Indonesia and the Philippines: Testing the mediating roles of perceived group threat and social dominance orientation and the moderating role of context. European Journal of Social Psychology, 46, 700-715. doi:10.1002/ejsp.2212
Khisbiyah, Y. (2009). Contested discourses on violence, social justice, and peacebuilding among Indonesian Muslims. In C.J. Montiel \& N.M. Noor (Eds.), Peace psychology in Asia (pp. 123-145). Dordrecht, the Netherlands: Springer. doi:10.1007/978-1-4419-0143-9_7

Knaap, G. (2014). Islamic resistance in the Dutch colonial empire. In D. Motadel (Ed.), Islam and the European empires. Oxford Scholarship Online.

Liht, J., Conway, L.G., Savage, S., White, W., \& O'Neill, K.A. (2011). Religious fundamentalism: An empirically derived construct and measurement scale. Archive for the Psychology of Religion-Archiv Fur Religionspsychologie, 33, 299-323. doi:10.1163/157361211x594159

Mavor, K.I., Louis, W.R., \& Laythe, B. (2011). Religion, prejudice, and authoritarianism: Is RWA a boon or bane to the psychology of religion? Journal for the Scientific Study of Religion, 50, 22-43. doi:j.1468-5906.2010.01550.x

Meeus, J., Duriez, B., Vanbeselaere, N., \& Boen, F. (2010). The role of national identity representation in the relation between in-group identification and out-group derogation: Ethnic versus civic representation. British Journal of Social Psychology, 49(Pt 2), 305-320. doi:10.1348/ 014466609X451455

Muhtadi, B. (2009). The quest for Hizbut Tahrir in Indonesia. Asian Journal of Social Science, 37, 623-645. doi:10.1163/ $156853109 \times 460219$

Mummendey, A., \& Wenzel, M. (1999). Social discrimination and tolerance in intergroup relations: Reactions to intergroup difference. Personality and Social Psychology Review, 3, 158-174.

Nakhleh, E. (2009). 'Moderates' redefined: How to deal with political Islam. Current History, 108, 402.

Osman, M.N.M. (2010a). Reviving the caliphate in the Nusantara: Hizbut Tahrir Indonesia's mobilization strategy and its impact in Indonesia. Terrorism and Political Violence, 22, 601-622. doi:10.1080/09546553.2010.496317

Osman, M.N.M. (2010b). The transnational network of Hizbut Tahrir Indonesia. South East Asia Research, 18, 735-755. doi:10.5367/sear.2010.0018

Pisani, E., \& Buehler, M. (2017). Why do Indonesian politicians promote Sharia laws? An analytic framework for Muslimmajority democracies. Third World Quarterly, 38, 734-752. doi:10.1080/01436597.2016.1206453

Pohl, F. (2015). 'I Come from a Pancasila family': A discursive study on Muslim-Christian identity transformation in Indonesian post-reformasi era. Journal of Ecumenical Studies, 50, 504-505.

Rieffer, B.-A.J. (2003). Religion and nationalism: Understanding the consequences of a complex relationship. Ethinicities, 3, 215-242.

Rogers, M.B., Loewenthal, K.M., Lewis, C.A., Amlot, R., Cinnirella, M., \& Ansari, H. (2007). The role of religious fundamentalism in terrorist violence: A social psychological analysis. International Review of Psychiatry, 19, 253-262. doi:10.1080/09540260701349399

Setijadi, C. (2017). Chinese Indonesians in the eyes of the Pribumi public. Perspective, No. 73, 1-12. 
Simon, B., Trotschel, R., \& Dahne, D. (2008). Identity affirmation and social movement support. European Journal of Social Psychology, 38, 935-946. doi:10.1002/ejsp. 473

Smith, A.D. (2001). Nationalism: Theory, ideology, history. Cambridge, UK: Polity Press.

Stankov, L., Saucier, G., \& Knezevic, G. (2010). Militant extremist mind-set: Proviolence, vile world, and divine power. Psychological Assessment, 22, 70-86. doi:10.1037/ a0016925.

Strathern, A. (2013). Why are Buddhist monks attacking Muslims?. BBC Magazine. Retrieved from https://www.bbc. com/news/magazine-22356306

Takwin, B., Mudzakkir, A., Salim, H., Ahnaf, M.I., \& Hamdi, A.Z. (2016). Studies on tolerance and radicalism in Indonesia: The learning taken from 4 different areas: Tasikmalaya, Yogyakarta, Bojonegoro and Kupang. Jakarta, Indonesia: The Wahid Institute.

Verkuyten, M., Maliepaard, M., Martinovic, B., \& Khoudja, Y. (2014). Political tolerance among Muslim minorities in Western Europe: The role of denomination and religious and host national identification. Politics and Religion, 7, 265-286. doi:10.1017/S1755048314000212
Verkuyten, M., \& Yildiz, A.A. (2007). National (dis)identification and ethnic and religious identity: A study among TurkishDutch Muslims. Personality and Social Psychology Bulletin, 33, 1448-1462.

Ward, K. (2009). Non-violent extremists? Hizbut Tahrir Indonesia. Australian Journal of International Affairs, 63, 149-164. doi:10.1080/10357710902895103

Webber, D., Babush, M., Schori-Eyal, N., Vazeou-Nieuwenhuis, A., Hettiarachchi, M., Belanger, J.J., . . . Gelfand, M.J. (2017). The road to extremism: Field and experimental evidence that significance loss-induced need for closure fosters radicalization. Journal of Personality and Social Psychology, 114, 270-285.

Wellman, J.K., \& Tokuno, K. (2004). Is religious violence inevitable? Journal for the Scientific Study of Religion, 43, 291296.

Williamson, W.P., \& Ahmad, A. (2007). Survey research and Islamic fundamentalism: A question about validity. Journal of Muslim Mental Health, 2, 155-176.

Ysseldyk, R., Matheson, K., \& Anisman, H. (2010). Religiosity as identity: Toward an understanding of religion from a social identity perspective. Personality and Social Psychology Review, 14, 60-71. 